\title{
KARAKTERISASI FISIKOKIMIA DAN AKTIVITAS ANTIOKSIDAN SERAT PANGAN DARI AMPAS EMPULUR SAGU BARUK (Arenga Microcarpha B.)
}

\author{
Nova $^{1 *}$, Edi Suryanto ${ }^{1}$, Lidya I. Momuat ${ }^{1}$ \\ ${ }^{1}$ Jurusan Kimia Fakultas Matematika dan Ilmu Pengetahuan Alam Universitas Sam Ratulangi, \\ Jl. Kampus Unsrat, Kleak, Manado 95115 Sulawesi Utara
}

\begin{abstract}
ABSTRAK
Telah dilakukan pengujian potensi aktivitas antioksidan serat pangan dari ampas empulur sagu baruk. Penelitian ini bertujuan untuk mengetahui potensi antioksidan dari ampas empulur sagu baruk. Hasil penelitian menunjukkan bahwa ampas empulur sagu baruk tidak mengalami perubahan mendasar pada komponen utama selama penggilingan ditunjukkan pada hasil spektra Fourier Transform Infra Red (FT-IR). Hasil analisis Particle Size Analysis (PSA) menunjukkan ukuran partikel dari ampas empulur sagu baruk sebesar 92,89 $\mu \mathrm{m}$. Analisis X-ray Difraction (XRD) menunjukkan adanya karakteristik dari selulosa yang merupakan bagian dari serat pangan tak larut. Hasil pengujian serat pangan didapatkan bahwa ampas empulur sagu baruk memiliki serat pangan total sebesar $68,71 \%$ yang meliputi $66,58 \%$ serat pangan tak larut dan $2,12 \%$ serat pangan larut. Kadar serat pangan tak larut meliputi kadar selulosa, hemiselulosa dan lignin yaitu $50,7 \%$; 29,16\%; dan 11,67\% secara berturut-turut. Hasil pengujian aktivitas antioksidan metode DPPH dari ekstrak fenolik terikat (EFT) dan fenolik bebas (EFB) ampas empulur sagu baruk menunjukkan aktivitas antioksidan sebesar $66,20 \%$ EFB dan 50,97\% EFT. Adapun kemampuan penangkal ion nitrit dari sampel ampas sagu baruk kering angin memiliki potensi menangkal ion nitrit sebesar 55,20\% EFB dan 50,15\% EFT.
\end{abstract}

Kata kunci : Ampas empulur agu baruk, antioksidan, serat pangan

\section{ABSTRACT}

Potential antioxidant activity of food fiber from barley sago pith pulp has been tested. This research studies the antioxidant potential of barley sago pith pulp. Fourier Transform Infra Red (FT-IR). The results showed the fact that the barley sago pith pulp did not change the basis of the main components during grinding evaluating the spectral results. The results of the analysis of Particle Size Analysis (PSA) showed that the particle size of the pith sago waste was $92.89 \mu \mathrm{m}$. X-ray Difraction (XRD) analysis shows the characteristics of cellulose which is part of insoluble dietary fiber. Food fiber test results were obtained from barley sago pith pulp having a total food fiber of $68.71 \%$ which contained $66.58 \%$ insoluble food fiber and $2.12 \%$ soluble food fiber. Insoluble dietary fiber content includes cellulose, hemicellulose and lignin levels that is $50.7 \% ; 29.16 \%$; and $11.67 \%$ consistently. The results of testing the antioxidant activity of DPPH method from phenolic extracts (EFT) and free phenolic (EFB) barley pith pulp showed antioxidant activity of $66.20 \%$ EFB and $50.97 \%$ EFT. Whereas the ability to prevent nitrite ions from dried barago sago pulp samples has the ability to counteract nitrite ions by $55.20 \%$ EFB and $50.15 \%$ EFT.

Keywords : Barley sago pith pulp, antioxidant, dietary fiber

\section{PENDAHULUAN}

Sulawesi Utara merupakan salah satu daerah yang memiliki kekayaan flora yang dapat dimanfaatkan sebagai tanaman pangan maupun obat. Salah satu tanaman pangan yang dapat digunakan sebagai pangan lokal adalah sejenis tanaman sagu yang disebut dengan sagu baruk. Sagu baruk (Arenga microcarpha B.) merupakan tanaman endemik yang dapat memproduksi karbohidrat yang banyak tumbuh di daerah Kabupaten Sitaro, Sangihe dan Talaud. Dalam proses pengolahan tepung sagu (Metroxylon sp) terdapat salah satu jenis limbah

\footnotetext{
* Korespondensi:

Telepon: +62 852-5510-4386

Email: nlatuhary@gmail.com

DOI: https://doi.org/10.35799/cp.13.1.2020.28931
}

perkebunan yaitu ampas sagu. Perbandingan tepung dengan ampas yang dihasilkan pada pengolahan tepung sagu adalah sekitar 1:6 (Islamiyati, 2009). Dalam pengolahan empulur sagu diperoleh $18,5 \%$ pati dan $81,5 \%$ berupa ampas. Menurut Fahri (2016), ampas sagu (Metroxylon $\mathrm{sp}$ ) terdiri dari serat-serat empulur yang diperoleh dari hasil pemarutan/ pemerasan isi batang sagu. Limbah ampas merupakan bahan lignoselulosa yang sebagian besar tersusun atas selulosa, hemiselulosa dan lignin.

Hemiselulosa, selulosa, lignin merupakan sisa dari dinding sel tumbuhan yang tidak terhidrolisis atau tercerna oleh enzim pencernaan manusia atau yang disebut serat 
pangan (Trowell dkk.,1985). Serat pangan terdiri atas serat pangan tak larut (insoluble dietary fiber) dan serat pangan larut (soluble dietary fiber) (Dodevska dkk., 2013).

Perlakuan mikronisasi tepung antioksidan serat pangan menghasilkan peningkatan kelarutan, kapasitas penyerapan air dan kapasitas penyerapan minyak (Raghavendra, 2004). Dimana ketika ukuran partikel lebih kecil, maka luas permukaan akan meningkat. Permukaan yang lebih besar memungkinkan interaksi yang lebih besar dengan pelarut dan menyebabkan peningkatan kelarutan. Metode pengurangan ukuran partikel memungkinkan terjadinya peningkatan kelarutan yang efisien, dapat direproduksi, dan ekonomis (Savjani dkk., 2012).

Antioksidan adalah suatu senyawa yang dapat menghambat atau memperlambat proses oksidasi. Oksidasi merupakan reaksi kimia yang melibatkan pengikatan oksigen, pelepasan hidrogen, atau pelepasan elektron. Untuk mencapai kestabilan atom radikal bebas akan bereaksi dengan molekul disekitarnya untuk memperoleh pasangan elektron. Reaksi ini akan berlangsung terus menerus dalam tubuh dan bila tidak dihentikan akan menimbulkan berbagai penyakit seperti kanker, jantung , katarak, penuaan dini, serta penyakit lainnya (Bjelakovic dkk., 2007).

Berdasarkan uraian diatas, peneliti tertarik melakukan penelitian untuk mengetahui potensi antioksidan serat pangan dari tepung empulur sagu baruk (Arenga microcarpha B).

\section{METODE PENELITIAN}

Penelitian ini dilakukan selama 4 bulan di UPT Laboratorium Terpadu, Universitas Sam Ratulangi, Manado. Pengujian FTIR, XRD, PSA, serat pangan, dan kadar protein dilaksanakan di Laboratorium Universitas Gadjah Mada. Sampel empulur sagu baruk diambil dari Desa Moronge, Kecamatan Moronge, Kabupaten Kepulauan Talaud, Sulawesi Utara.

\section{Alat dan bahan}

Alat yang digunakan yaitu gelas kimia, kertas saring, aluminium foil, timbangan analitik, blender, milling (Fomac tipe FCTZ200 tegangan $220 \mathrm{~V}$ daya $1 \mathrm{KW}$ frekuensi 50$60 \mathrm{~Hz}$ kecepatan putar $28.000 \mathrm{rpm}$ ), ayakan 35 dan 200 mesh, rak tabung, mikro pipet, gelas ukur, oven, petridis, desikator, sudip, botol vial, penangas air, batang pengaduk, tanur, inkubator, spektrofotometer UV-Vis (Shimadzu), rotary evaporator, dan vortex mixer. Bahan yang digunakan dalam penelitian yaitu etanol, natrium karbonat $2 \%$, reagen Folin-Ciocelteau $50 \%$, petroleum eter, asam klorida, dan natrium hidroksida, buffer fosfat, aseton dan asam sulfat diperoleh dari MERCK (Darmstadt, Germany). Asam sulfanilat, N-(1Naphthyl)ethylenediamine, dan larutan 1,1difenil-2pikrilhidrazil (DPPH), natrium nitrit diperoleh dari Sigma-Aldrich (St. Louis MO, USA).

\section{Preparasi sampel}

Sampel ampas sagu baruk diperlakukan dengan cara pengeringan oven pada $50-60{ }^{\circ} \mathrm{C}$ sampai kadar air $<7 \%$. Setelah itu, sampel dihancurkan dengan blender dan diayak menggunakan ayakan 35 mesh. Serbuk hasil ayakan 35 mesh kemudian dihaluskan (mikronisasi) dengan alat milling (Fomac tipe FCT-Z200 tegangan $220 \mathrm{~V}$ daya $1 \mathrm{KW}$ frekuensi $50-60 \mathrm{~Hz}$ kecepatan putar 28.000 rpm) selama 2 menit. Hasil miling dalam bentuk tepung, kemudian diayak menggunakan ayakan 200 mesh $(74 \mu \mathrm{m})$. Sampel yang diperoleh dari 200 mesh disimpan untuk dilakukan pengujian.

\section{Karakterisasi fisik}

Sampel tepung ampas empulur sagu baruk dikarakterisasi untuk mengetahui karakteristik fisik dari sampel tersebut. Analisis yang dilakukan yaitu menggunakan Particles Sized Analyzer (PSA), Fourier Transform Infra Red (FT-IR) dan X-ray Difraction (XRD).

\section{Karakterisasi kimia}

Komposisi kimia meliputi kadar air, kadar abu, dan kadar lemak dari tepung ampas empulur sagu baruk ditentukan dengan menggunakan metode Sudarmadji (1997), sedangkan kadar protein mengikuti prosedur SNI (01-2891-1992). Adapun analisis kandungan serat pangan ditentukan menggunakan metode AOAC (1995).

\section{Analisis kadar hemiselulosa, selulosa dan lignin}

Analisis kadar hemiselulosa, selulosa, lignin dari tepung ampas empulur sagu baruk dilakukan dengan metode fraksinasi dari Chesson (1978) dalam Datta (1981), tepung ampas sagu baruk ditimbang sebanyak $2 \mathrm{~g}$ (a) kemudian dimasukkan ke dalam gelas beker, 
ditambah aquades sebanyak $150 \mathrm{~mL}$ dan dipanaskan pada penangas air pada $100{ }^{\circ} \mathrm{C}$ selama 2 jam. Sampel yang sudah berbentuk bubur disaring kemudian dicuci dengan aquades sampai volume filtrat tepat $300 \mathrm{~mL}$. Residu dikeringkan dalam oven dengan suhu $105{ }^{\circ} \mathrm{C}$ sampai mencapai berat konstan (b). Residu yang sudah kering dimasukkan dalam labu Erlenmeyer $250 \mathrm{ml}$, kemudian ditambah $150 \mathrm{~mL} \mathrm{H}_{2} \mathrm{SO}_{4} 1 \mathrm{~N}$ dan direfluks diatas penangas air pada suhu $100{ }^{\circ} \mathrm{C}$ selama 1 jam. Selanjutnya larutan disaring dan residu dicuci dengan aquades sampai volume filtrat mencapai $500 \mathrm{~mL}$ (netral). Residu dikeringkan dan ditimbang (c). Residu kering dimasukkan lagi ke dalam Erlenmeyer $250 \mathrm{~mL}$ ditambah $10 \mathrm{~mL}$ $\mathrm{H}_{2} \mathrm{SO}_{4} 72 \%$ dan didiamkan selama 4 jam pada suhu kamar, kemudian ditambah $150 \mathrm{~mL}$ $\mathrm{H}_{2} \mathrm{SO}_{4} 1 \mathrm{~N}$ dan direfluks pada pendingin balik pada suhu $100{ }^{\circ} \mathrm{C}$ selama 1 jam. Selanjutnya larutan disaring dan dicuci dengan air panas sampai netral (volume filtrat mencapai 400 $\mathrm{mL}$ ). Residu dikeringkan dan ditimbang (d) selanjutnya diabukan dan ditimbang (e).

kadar fraksi hemiselulosa $=\frac{\mathrm{b}-\mathrm{c}}{\mathrm{a}} \times 100 \% \mathrm{~b} / \mathrm{b}$ kadar fraksi selulosa $=\frac{\mathrm{c}-\mathrm{d}}{\mathrm{a}} \times 100 \% \mathrm{~b} / \mathrm{b}$

kadar fraksi lignin $=\frac{\mathrm{d}-\mathrm{e}}{\mathrm{a}} \times 100 \% \mathrm{~b} / \mathrm{b}$

Keterangan: $\quad a=$ berat kering bahan; $b=$ berat kering setelah diekstraksi dengan aquades; $\mathrm{c}=$ fraksi yang larut dalam $\mathrm{H}_{2} \mathrm{SO}_{4} 1 \mathrm{~N}$; $\mathrm{d}=$ fraksi yang larut dalam $\mathrm{H}_{2} \mathrm{SO}_{4} \quad 72 \%$; e=kadar abu bahan

\section{Ekstraksi fenolik bebas dan fenolik terikat}

Sebanyak $5 \mathrm{~g}$ tepung ampas empulur sagu baruk diekstraksi menggunakan teknik ekstraksi maserasi dengan pelarut etanol $80 \%$ selama 24 jam. Selanjutnya disaring menggunakan kertas saring sehingga diperoleh filtrat. Filtrat kemudian dievaporasi pada suhu $40{ }^{\circ} \mathrm{C}$ sehingga diperoleh ekstrak fenolik bebas (EFB). Setelah itu, ampas dari EFB sebanyak 5 $\mathrm{g}$ dihidrolisis dengan $40 \mathrm{~mL} \mathrm{NaOH} 2 \mathrm{M}$ sambil diaduk pada suhu kamar selama 1 jam. Selanjutnya, campuran dinetralkan dengan $\mathrm{HCl}$ sampai pH 6 dan diekstraksi tiga kali dengan etil asetat sampai bening. Fraksi etil asetat dievaporasi pada $40{ }^{\circ} \mathrm{C}$ sehingga didapat ekstrak fenolik terikat (EFT). Kemudian, ekstrak EFB dan EFT yang diperoleh ditimbang dan disimpan pada suhu $5{ }^{\circ} \mathrm{C}$ sebelum dianalisis kandungan fitokimia dan pengujian aktivitas antioksidan.

\section{Penentuan kandungan total fenolik}

Kandungan total fenolik dalam tepung ampas empulur sagu baruk ditentukan menggunakan metode Jeong dkk. (2005), sebanyak $0,1 \mathrm{~mL}$ masing-masing ekstrak kental dimasukkan dalam tabung reaksi, lalu ditambahkan $0,1 \mathrm{~mL}$ reagen Folin-Ciocalteau $50 \%$. Campuran tersebut divortex selama 2 menit, lalu ditambahkan $2 \mathrm{~mL}$ larutan natrium karbonat $2 \%$. Selanjutnya campuran diinkubasi dalam ruang gelap selama 30 menit. Absorbansinya dibaca pada panjang gelombang $750 \mathrm{~nm}$ dengan spektrofotometer. Kandungan total fenol dinyatakan sebagai ekivalen asam galat $\mu \mathrm{g} / \mathrm{mL}$ ekstrak.

\section{Penentuan aktivitas penangkal radikal bebas}

Penentuan aktivitas penangkal radikal bebas tepung ampas empulur sagu baruk ditentukan dengan metode Burda \& Oleszeck (2001), sebanyak 0,5 mL masing-masing ekstrak ditambahkan dengan $1,5 \mathrm{~mL}$ larutan 1,1-difenil-2-pikrilhidrazil (DPPH) dan divortex selama 2 menit. Berubahnya warna larutan dari ungu ke kuning menunjukan efisiensi penangkal radikal bebas. Selanjutnya pada 5 menit terakhir menjelang 30 menit inkubasi, absorbansinya diukur pada panjang gelombang $517 \mathrm{~nm}$ dengan menggunakan spektrofotometer UV-VIS. Aktivitas penangkal radikal bebas (APRB) dihitung sebagai presentase berkurangnya warna DPPH dengan menggunakan persamaan:

$\operatorname{APRB}(\%)=\left(1-\frac{\text { absorbansi sampel }}{\text { absorbansi kontrol }}\right) \times 100 \%$

\section{Kapasitas penangkal nitrit}

Kapasitas penangkal nitrit (KPN) ditentukan menggunakan metode Wang dalam Zhang dkk. (2009), $2 \mathrm{~mL}$ natrium nitrit $5 \mathrm{mg} / \mathrm{L}$ dicampur dengan $3 \mathrm{~mL}$ ekstrak dalam labu 25 $\mathrm{mL}$ pada suhu kamar selama 30 menit. Larutan campuran dicampur dengan $1 \mathrm{~mL}$ asam sulfanilat $0,4 \%$ distirer selama 5 menit diikuti penambahan $0,5 \quad \mathrm{~mL} \quad \mathrm{~N}-(1-$ Naphthyl)ethylenediamine $0,1 \%$ dan volume disesuaikan menjadi $25 \mathrm{~mL}$ dengan aquades. Larutan didiamkan selama 15 menit dan diukur absorbansi menggunakan Spektrofotometer UV-Vis pada $\lambda 538 \mathrm{~nm}$. Kapasitas penangkal ion nitrit (\%) dihitung menggunakan rumus : 


$$
\operatorname{KPN}(\%)=\left(\frac{A_{0}-\left(A_{1}-A_{2}\right)}{A_{0}}\right) \times 100 \%
$$

Keterangan: $\quad \mathrm{A}_{0}=$ Absorbansi $\mathrm{NaNO}_{2}$; $\mathrm{A}_{1}=$ Absorbansi $\mathrm{NaNO}_{2}$ dan ekstrak; $\mathrm{A}_{2}=$ Absorbansi ekstrak

\section{Analisis statistik}

Semua data eksperimen dilakukan dua kali ulangan dan hasilnya dinyatakan sebagai rataan \pm SD. Analisis dilakukan menggunakan software SPSS versi 12.

\section{HASIL DAN PEMBAHASAN}

\section{Rendemen ampas empulur sagu baruk}

Rendemen ampas empulur sagu baruk dihitung untuk mengetahui seberapa banyak rendemen yang dihasilkan untuk perlakuan pengeringan ampas empulur sagu baruk. Dari 1 $\mathrm{kg}$ ampas empulur sagu baruk yang telah dikeringkan, digiling dan diayak menggunakan ayakan 35 mesh menghasilkan rendemen sebesar $8,68 \%$. Selanjutnya hasil mikronisasi dengan alat Fomac tipe FCT-Z200 dan diayak menggunakan 200 mesh diperoleh rendemen sebesar $97,8 \%$. Berdasarkan hasil rendemen yang diperoleh, alat milling dapat menghaluskan sampel hingga berukuran mikro.

\section{Komposisi kimia}

Tepung ampas empulur sagu baruk yang diperoleh selanjutnya dianalisis komposisi kimia yang meliputi kadar air, abu, protein, lemak, serat pangan dan karbohidrat (by different). Hasil komposisi kimia tepung ampas empulur sagu baruk disajikan pada Tabel 1.

Tabel 1. Komposisi kimia dari tepung ampas empulur sagu baruk

\begin{tabular}{lc}
\hline Komponen & Persentasi (\%) \\
\hline Kadar air & $5,74 \pm 0,26$ \\
Kadar abu & $2,30 \pm 0,13$ \\
Kadar protein & $2,04 \pm 0,05$ \\
Kadar lemak & $0,27 \pm 0,46$ \\
Serat pangan tak larut & $66,58 \pm 0,01$ \\
Serat pangan larut & $2,12 \pm 0,04$ \\
Serat pangan total & $68,71 \pm 0,07$ \\
Karbohidrat non-serat $($ by diff*) & $11,71 \pm 0.23$ \\
\hline
\end{tabular}

*) Karbohidrat non-serat: 100\%- (kadar air+ kadar abu + kadar protein + kadar lemak + serat pangan total)

Hasil penelitian kadar air tepung ampas empulur sagu baruk sebesar 5,74\% diduga disebabkan pengaruh suhu yang diberikan saat mengeringkan sampel, dimana suhu oven berada pada $55-60{ }^{0} \mathrm{C}$, semakin tinggi suhu udara maka jumlah air yang diuapkan semakin banyak sehingga bahan yang dikeringkan memiliki kadar air yang rendah pula. Kadar abu pada suatu bahan pangan menunjukkan terdapatnya kandungan mineral anorganik pada bahan pangan tersebut. Hasil analisis kadar abu yang diperoleh dari tepung ampas empulur sagu baruk sebesar 2,30\%. Hasil pengujian kadar abu pada sampel cukup tinggi jika dibandingkan dengan tepung sagu baruk yang diteliti oleh Momuat dkk. (2016) yaitu $0,03 \%$. Hal ini terjadi diduga sampel sagu baruk yang digunakan merupakan bagian empulur sagu yang telah diperas dan menjadi ampas sehingga diduga terdapat banyak unsur-unsur mineral yang terdapat pada sisa pembakaran. Tinggi rendahnya kadar abu yang terkandung dalam suatu bahan dapat dihubungkan dengan jumlah unsur mineral (Ratana-arporn \& Chirapart, 2006). Kandungan protein dari tepung ampas empulur sagu baruk yaitu 2,04\% diduga disebabkan oleh pengaruh suhu pada saat preparasi. Sesuai dengan pendapat Sundari dkk. (2015), semakin tinggi suhu yang digunakan mengakibatkan kadar protein pada bahan pangan semakin menurun. Hasil analisis kadar lemak yaitu sebesar $0,27 \%$ diduga disebabkan proses pemarutan masih terdapat sedikit kadar lemak yang tertinggal di ampas sagu baruk. Hasil analisis serat pangan total adalah $68,71 \%$ yang terdiri dari serat pangan tak larut $66,58 \%$ dan serat pangan larut 2,12\%. Berdasarkan hasil tersebut diduga serat pangan dari ampas empulur sagu baruk tidak dipengaruhi oleh proses pemarutan dan penggilingan. Sehingga masih terdapat kandungan serat pangan dalam tepung ampas empulur sagu baruk.

\section{Kandungan hemiselulosa, selulosa dan lignin} Penentuan kandungan hemiselulosa, selulosa dan lignin ditentukan menggunakan metode Chesson, (1978) yang dijelaskan oleh Datta (1982) yaitu metode dengan prinsip gravimetri. Hasil pengujian kandungan hemiselulosa, selulosa dan lignin yang ditunjukkan pada Tabel 2. 
Tabel 2. Kandungan hemiselulosa, selulosa dan lignin dari tepung ampas empulur sagu baruk(TAESB)

\begin{tabular}{llc}
\hline $\begin{array}{c}\text { Kandungan } \\
(\%)\end{array}$ & TAESB & $\begin{array}{c}\text { *Ampas sagu } \\
\text { (Metroxylon } \mathrm{sp} .)\end{array}$ \\
\hline Hemiselulosa & $29,16 \pm 0,82$ & 14,60 \\
Selulosa & $50,7 \pm 0,78$ & 36,30 \\
Lignin & $11,67 \pm 0,13$ & 9,70 \\
\hline
\end{tabular}

*) Perbandingan ampas sagu (Metroxylon sp.) oleh Sangaji (2009)

Berdasarkan Tabel 2. nilai kandungan hemiselulosa, selulosa dan lignin cukup tinggi jika dibandingkan dengan ampas sagu jenis (Metroxylon sp.) yang diteliti oleh Sangaji (2009). Hal tersebut diduga disebabkan oleh jenis sagu yang berbeda, pada penelitian ini sampel sagu yang digunakan adalah sagu baruk (Arenga microcarpha B) sedangkan penelitian oleh Sangaji (2009) menggunakan sagu (Metroxylon sp.). Kemungkinan lain yaitu metode yang digunakan dalam penelitian ini berbeda dengan metode yang digunakan pada penelitian Sangaji.

\section{Pengujian (Fourier Transform Infra-Red) FT-IR}

Spektroskopi FT-IR digunakan untuk mengetahui struktur kimia yang dihasilkan dari tepung ampas empulur sagu baruk. Spektrum FT-IR dari 400 hingga $4000 \mathrm{~cm}^{-1}$ yang dihasilkan oleh tepung ampas empulur sagu baruk (TAESB) dan mikrokristal selulosa (SMK) dapat dilihat pada Gambar 1.

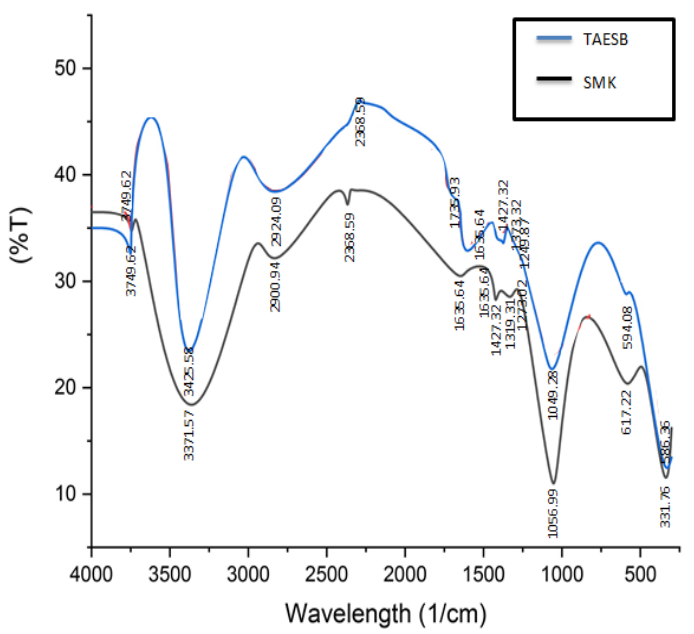

Gambar 1. Spektrum FTIR dari ampas empulur sagu baruk dan mikrokristalselulosa (SMK)

Absorpsi yang kuat dan luas berdasarkan Gambar 1. berada pada daerah serapan $3425,58 \mathrm{~cm}^{-1}$ menunjukkan getaran O$\mathrm{H}$ yang dikaitkan dengan peregangan $\mathrm{O}-\mathrm{H}$ dari gugus hidroksil yang berasal terutama dari selulosa (Baeza dkk., 2001). Puncak pada bilangan gelombang $2924.09 \mathrm{~cm}^{-1}$ mewakili peregangan $\mathrm{C}-\mathrm{H}$ dari selulosa (Baeza dkk., 2001) pada SMK ditandai pada bilangan gelombang $2900.94 \mathrm{~cm}^{-1}$. Puncak disekitar $1735.93 \mathrm{~cm}^{-1}$ merupakan ciri-ciri atau peregangan dari selulosa (Popescu dkk., 2009). Pada spektrum terdapat serapan di $1427.32 \mathrm{~cm}^{-1}$ dimana daerah serapan sekitar $1420 \mathrm{~cm}^{-1}$ menunjukkan ikatan $-\mathrm{CH}_{2}$ yang berdeformasi dalam selulosa (Shanmugarajah dkk., 2015) hasil ini sesuai dengan sampel SMK yang memiliki puncak yang sama pada bilangan gelombang $1427.32 \mathrm{~cm}^{-1}$. Getaran yang menonjol di sekitar $1044 \mathrm{~cm}^{-1}$ merupakan peregangan $\mathrm{C}-\mathrm{O}, \mathrm{C}-\mathrm{C}$ atau pembengkokan $\mathrm{C}-\mathrm{OH}$ dalam xilan (Peng dkk., 2010). Dimana xilan merupakan komponen terbesar penyusun hemiselulosa dinding sel tanaman dan termasuk dalam jenis polisakarida paling berlimpah kedua setelah selulosa yang menyusun stuktur dinding sel tumbuhan (Nareswari, 2007). Pada sampel terlihat pada bilangan gelombang $1049.28 \mathrm{~cm}^{-1}$. Lignin ditunjukan dengan adanya puncak antara 1200-1300 $\mathrm{cm}^{-1}$ dengan perengangan dari kerangka aromatik (Reddy dkk., 2005) pada spektrum ditunjukkan dengan adanya puncak $1249.87 \mathrm{~cm}^{-1}$. Berdasarkan uraian tersebut sampel tepung ampas empulur sagu baruk memiliki nilai bilangan gelombang yang relatif sama dengan ciri-ciri selulosa, hemiselulosa dan lignin. Hal tersebut diduga tidak ada terjadi pergeseran selama proses mikronisasi. Menurut Zhao dkk. (2015), pergeseran menunjukkan bahwa proses pengahalusan menggunakan milling dapat memutus ikatan hidrogen intramolekul, yang mungkin dikaitkan dengan degradasi selulosa (Ma \& Mu, 2016). Tidak ada perubahan signifikan dalam bentuk puncak spektrum FTIR, yang menunjukkan tidak ada perubahan mendasar pada komponen utama setelah penggilingan, dipastikan bahwa bahan aktif serat makanan tidak hancur selama perlakuan penggilingan (Liu dkk., 2016).

\section{Pengujian $X$-ray Difractiion (XRD)}

Pengujian XRD dilakukan untuk mengetahui dua tipe data, yaitu kualitatif dan kuantitatif dengan mengetahui posisi $2 \theta$ pada tiap puncak yang terdeteksi oleh XRD. Dengan mengetahui besarnya intensitas relatif deretan puncak-puncak difraksi tersebut maka dapat diketahui senyawa penyusun material tersebut. 

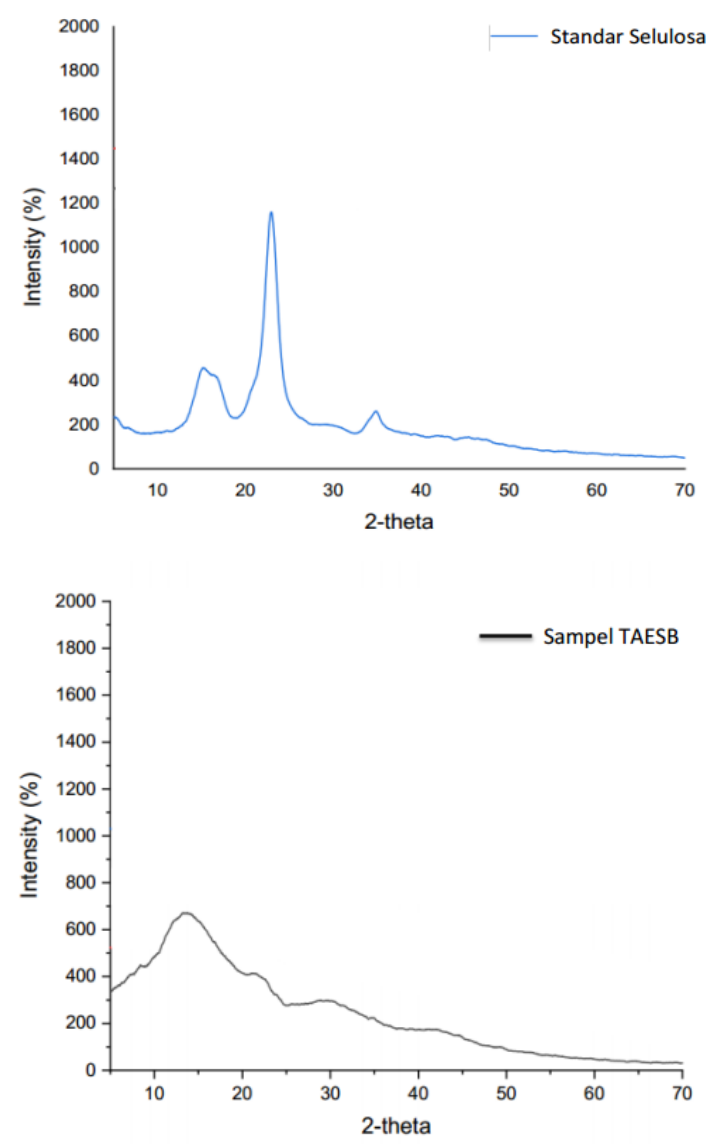

Gambar 2. Pola difraktrogram sinar-X pada sampel tepung ampas empulur sagu baruk (TAESB) dan standar selulosa
Seperti yang terlihat pada Gambar 2. pola difraktogram sinar-X pada tepung ampas empulur sagu baruk menunjukkan puncak $2 \theta$ yang menonjol, berdasarkan Tabel 3. puncak disekitar $13,8^{0}$ dan $21,8^{0}$ dengan nilai Full Width Half Maximum (FWHM) sebesar $8,43 / 2,71$. Jika dibandingkan dengan pola difraksi dari standar selulosa yakni mikrokristal selulosa yang ditampilan Gambar 2. berdasarkan Tabel 3. kristalitas mikrokristal selulosa sebesar $60,29 \%$ dengan posisi puncak $2 \theta$ berada pada $15,04^{\circ}$ dan $22,72^{\circ}$. Dilihat dari posisi puncak sampel tepung ampas empulur sagu baruk diduga bahwa daerah kristalin pada sampel tidak hancur selama proses mikronisasi. Berdasarkan Gambar 2. pola yang ditampilkan oleh sampel memiliki pola yang relatif berbeda dengan mirkokristal selulosa namun, pada Tabel 3. munculnya puncak $2 \theta$ pada mikrokristal selulosa disekitar $22,72^{0}$ diduga merupakan puncak yang dihasilkan oleh selulosa. Hal ini menandakan bahwa sampel tepung ampas empulur sagu baruk memiliki kandungan selulosa yang hampir sama dengan mikrokristal selulosa yaitu $21,8^{0}$.

Tabel 3. Karakteristik kristalitas dari TAESB dan standar selulosa

\begin{tabular}{llllc}
\hline Sampel & $\begin{array}{l}\text { Sudut puncak } \\
\text { difraksi }\left(2 \theta /{ }^{0}\right)\end{array}$ & $\begin{array}{l}\text { Intensitas } \\
\text { Puncak }\end{array}$ & FWHM & $\begin{array}{c}\text { Kristalinitas } \\
(\%)\end{array}$ \\
\hline TAESB & $13,8 / 21,8$ & $738 / 468$ & $8,43 / 2,71$ & 22,42 \\
Mikrokristal selulosa & $15,04 / 22,72$ & $500 / 1260$ & $4,97 / 1,6$ & 60,29 \\
\hline
\end{tabular}

Ket: TAESB (Tepung ampas empulur sagu baruk), FWHM (Full Width Half Maximum).

\section{Pengujian (Particle size analysis) PSA}

Distribusi ukuran partikel dari sampel tepung ampas empulur sagu baruk ditunjukan pada Gambar 3. Dari hasil distribusi ukuran partikel pada Gambar 3. menunjukkan bahwa ukuran partikel didistribusikan pada kisaran 2,599 $\mu \mathrm{m}$ hingga 394,244 $\mu \mathrm{m}$. Hasil pengukuran PSA berbentuk distribusi sehingga dapat menentukan ukuran partikel secara keseluruhan.

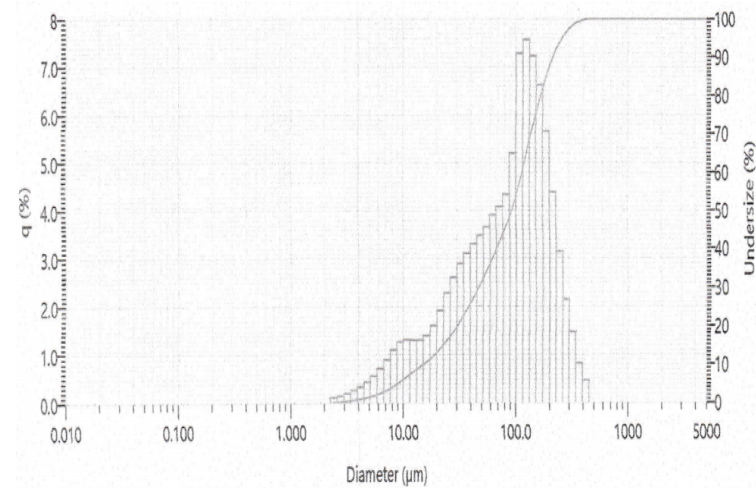

Gambar 3. Grafik distribusi ukuran partikel dari tepung ampas empulur sagu baruk 
Untuk mengukur luas distribusi ukuran partikel dilakukan perhitungan span. Span menunjukkan jarak antara titik $10 \%$ dan $90 \%$ yang berjarak sama dari median. Nilai span yang semakin kecil menunjukkan ukuran partikel yang lebih seragam dengan ditandai oleh lebar grafik distribusi ukuran partikel. Distribusi ukuran partikel dikarakterisasi dengan nilai $\mathrm{D}_{0.1}, \mathrm{D}_{0.5}$, dan $\mathrm{D}_{0.9}$ (Giry dkk., 2006). Nilai $\mathrm{D}_{0.1}, \mathrm{D}_{0.5}$, dan $\mathrm{D}_{0.9}$ adalah diameter volume ekivalen masing-masing pada volume kumulatif $10 \%$, 50\%, dan 90\%. Selanjutnya nilai span didefinisikan sebagai lebar distribusi ukuran partikel: $\quad \operatorname{Span}=\left(\mathrm{D}_{0.9}-\mathrm{D}_{0.1}\right) \quad / \mathrm{D}_{0.5}$ (Dyankova dkk., 2013). Diameter rata-rata dan nilai Span dari sampel tepung ampas empulur sagu baruk ditunjukkan pada Tabel 4.

Tabel 4. Distribusi ukuran partikel tepung

\begin{tabular}{ll}
\multicolumn{2}{c}{ ampas empulur sagu baruk } \\
\hline Ukuran partikel \\
\hline $\mathrm{D}_{0.1}(\mu \mathrm{m})$ & 15,48 \\
$\mathrm{D}_{0.5}(\mu \mathrm{m})$ & 92,89 \\
$\mathrm{D}_{0.9}(\mu \mathrm{m})$ & 215,13 \\
$\operatorname{Span}^{\mathrm{a}}(\mu \mathrm{m})$ & 2,15 \\
\hline
\end{tabular}

Berdasarkan Tabel 4. ukuran partikel $10 \%$ sebesar $15,48 \mu \mathrm{m}$, nilai median atau ukuran partikel $50 \%$ pada sampel yaitu 92,89 $\mu \mathrm{m}$ dan ukuran partikel $90 \%$ dari sampel adalah 215,13\%. Dari data ini dapat diketahui bahwa sampel dapat dimikronisasi menggunakan alat Fomac tipe FCT-Z200 sehingga mendapatkan ukuran partikel 92,89 $\mu \mathrm{m}$. Kecilnya nilai span menunjukkan sampel memiliki ukuran partikel yang lebih seragam.

\section{Rendemen dan kandungan fenolik ekstrak}

Sampel yang digunakan dalam penelitian ini adalah tepung ampas empulur sagu baruk yang diekstraksi menggunakan metode ekstraksi maserasi. Ekstraksi tepung ampas empulur sagu baruk dengan pelarut etanol $80 \%$ digunakan untuk mendapatkan ekstrak fenolik bebas (EFB) sedangkan residu hasil ekstraksi fenolik bebas dihidrolisis dengan asam dan basa untuk mendapatkan ekstrak fenolik terikat (EFT). Tabel 5. menunjukkan rendemen dari ekstrak dan kandungan total fenolik.

Tabel 5. Rendemen hasil ekstraksi dan kandungan total fenolik dari tepung ampas empulur sagu baruk

\begin{tabular}{lcc}
\hline Jenis ekstraksi & Rendemen (\%) & Total Fenolik $(\mu \mathrm{g} / \mathrm{mL})$ \\
\hline Ekstraksi Fenolik Bebas (EFB) & 1,76 & $47,63 \pm 1,28^{\mathrm{a}}$ \\
Ekstraksi Fenolik Terikat (EFT) & 2,20 & $39,68 \pm 0,48^{\mathrm{b}}$ \\
\hline
\end{tabular}

Dari data pada Tabel 5. diketahui bahwa tepung ampas empulur sagu baruk menghasilkan nilai rendemen EFB yaitu sebesar $1,76 \%$ dan EFT sebesar 2,20\%. Tingginya rendemen EFT diduga disebabkan ukuran partikel yang semakin kecil setelah dilakukan ektraksi fenolik bebas sehingga luas permukaan semakin besar. Pada Tabel 5. juga menunjukkan nilai total fenolik EFB yaitu $47,63 \mu \mathrm{g} / \mathrm{mL}$ dan EFT $39,68 \mu \mathrm{g} / \mathrm{mL}$. Nilai total fenolik pada sampel EFT cukup tinggi, hal tersebut diduga bahwa pada serbuk sisa penyaringan selama diekstraksi menggunakan basa dan asam masih terdapat bahan aktif pada sampel. Hal ini sesusai dengan penelitian Parra et al. (2007) yang menyatakan bahwa saat dilakukan proses hidrolisis dari residu hasil ekstrak (ekstrak fenolik terikat) ternyata masih banyak kandungan senyawa fenolik yang terkandung dalam residu tersebut.

\section{Aktivitas penangkal radikal bebas dan ion nitrit}

Pengukuran aktivitas antioksidan ekstrak tepung ampas empulur sagu baruk menggunakan radikal bebas DPPH (1,1diphenyl-2-picryhydrazil) sebagai media pengujian aktivitas penangkal radikal bebas. Pengujian aktivitas penangkal radikal dilakukan dengan mereaksikan ekstrak dengan larutan DPPH dan selanjutnya dibaca absorbansinya pada panjang gelombang $517 \mathrm{~nm}$. Penurunan intensitas warna larutan DPPH terjadi akibat pelepasan atom hidrogen dari senyawa fenolik kepada elektron yang tidak berpasangan yang terdapat pada senyawa DPPH. Hasil pengujian aktivitas penangkal radikal bebas DPPH dan penangkal ion nitrit dari ekstrak tepung ampas empulur sagu baruk konsentrasi $1000 \mu \mathrm{g} / \mathrm{mL}$ pada sampel dapat dilihat pada Tabel 6 . 
Tabel 6. Aktivitas penangkal radikal bebas dan penangkal ion nitrit dari tepung ampas empulur sagu baruk

\begin{tabular}{lcc}
\hline \multicolumn{1}{c}{ Jenis ekstraksi } & $\begin{array}{c}\text { Aktivitas penangkal radikal } \\
\text { bebas DPPH (\%) }\end{array}$ & $\begin{array}{c}\text { Aktivitas penangkal } \\
\text { ion nitrit (\%) }\end{array}$ \\
\hline Ekstrak Fenolik Bebas (EFB) & $66,20 \pm 0,33$ & $55,20 \pm 0,64$ \\
Ekstrak Fenolik Terikat (EFT) & $50,97 \pm 0,93$ & $50,15 \pm 0,11$ \\
\hline
\end{tabular}

Hasil pengujian aktivitas penangkal radikal bebas dari Tabel 6 . terhadap ekstrak tepung ampas empulur sagu baruk yang terdiri dari EFB sebesar $66,20 \%$ dan EFT sebesar $50,97 \%$. Sedangkan aktivitas penangkal ion nitrit yaitu $55,20 \%$ EFB dan 50,15 EFT. Tingginya nilai EFB dibanding EFT pada pengujian aktivitas penangkal radikal bebas dan penangkal ion nitrit diduga disebabkan metode ektraksi fenolik bebas mampu mengekstrak lebih banyak senyawa dibandingkan metode ekstraksi fenolik terikat.

\section{KESIMPULAN}

Pada karakteristik fisik FTIR pada sampel tepung ampas empulur sagu baruk diduga tidak ada perubahan mendasar pada komponen utama setelah penggilingan. Hasil analisis XRD juga menunjukkan bahwa proses mirkonisasi tidak merusak struktur kristal dari sampel, hal ini ditandai dengan terdapatnya puncak pada difraktogram yang mencirikan puncak kristalin dari mikrokristal selulosa. Hasil analisis PSA menunjukkan bahwa sampel tepung ampas empulur sagu baruk memiliki ukuran partikel sebesar $92,89 \mu \mathrm{m}$. Pada karakteristik kimia dari sampel didapatkan nilai total serat pangan tak larut cukup tinggi, hal tersebut sejalan dengan kandungan selulosa, hemiselulosa dan lignin yang tinggi pada sampel. Pengujian kandungan total fenolik, penangkal radikal bebas dan penangkal ion nitrit pada ekstrak EFB lebih tinggi dibanding EFT. Hal ini diduga metode ektraksi fenolik bebas (EFB) mampu mengekstrak lebih banyak senyawa dibandingkan metode ekstraksi fenolik terikat (EFT).

\section{DAFTAR PUSTAKA}

AOAC. (1995). Official methods of analysis of association of official analytical chemist. AOAC International. Virginia USA.

Baeza, J. \& Freer, J. in: D.N.-S. Hon, N. Shiraishi (Eds.), Chemical characterization of wood and its components: wood and cellulosic chemistry. New York: Marcel Dekker.
Bjelakovic, G., Nikolova, D., Gluud, L., Simonetti, R.G. \& Gluud,C. 2007. Mortality in randomized trials of antioxidant supplements for primary and secondary prevention: systematic review and meta-analysis. Journal of the American Medical Association. 297(8), 842-857.

Burda, S. \& Oleszek, W. 2001. Antioxidant and antiradical activities of flavonoids. Journal of Agricultural and Food Chemistry. 49(6), 2774-2779.

Datta, R. 1981. Acidogenic fermentation of lignocellulose-acid yield and conversion of components. Biotechnology and Bioengineering. 23(9), 2167-2170.

Dodevska, M.S., Djordjevic, B.I., Sobajic, S.S., Miletic, I.D., Djordjevic, P.B. \& Dimitrijevic-Sreckovic, V.S. 2013. Characterisation of dietary fibre components in cereals and legumes used in Serbian diet. Food Chemistry. 141(3), $1624-1629$.

Dyankova, S., Doneva, M., Todoorv, Y. \& Terziyka, M. 2013. Determination of particle size distribution and analysis of a natural food supplement on pectin base. Journal of Pharmacy. 6(5), 1-8.

Fahri, F. 2016. Penelitian pembuatan etanol dari serat/ampas sagu. Jurnal Penelitian Teknologi Industri. 8(1), 11-22.

Giry, K., Pean, J.M., Giraud, L., Marsas, S., Rolland, H. \& Wuthrich, P. 2006. Drug/lactose co-micronization by jet milling to improve aerosolization properties of a powder for inhalation. International Journal of Pharmaceutics. 321(1-2), 162-166.

Islamiyati, R. 2009. Kandungan nutrisi campuran ampas sagu (Metroxylon sp.) dan feses broiler yang difermentasi dengan berbagai level EM4. Makalah pada Seminar Nasional Teknologi Peternakan dan Veteriner. Fakultas Peternakan Universitas Hasanuddin. Makassar.

Jeong, S.M., Kim, S.Y., Kim. D.R, Jo, S.C., Nam, K.C., Ahn, D.U. \& Lee, S.C. 2004. 
Effect of heat treatment on the antioxidant activity of extracts from Citrus Peels. Journal of Agriculture and Food Chemistry. 52(11), 3389-3393.

Liu, Y., Wang, L., Liu, F. \& Pan, S. 2016. Effect of grinding methods on structural, physicochemical, and functional properties of insoluble dietary fiber from orange peel. International Journal of Polymer Science. 2016, 1-7.

Ma, M. \& Mu, T. 2016. Modification of deoiled cumin dietary fiber with laccase and cellulase under high hydrostatic pressure. Carbohydrate Polymers. 136, 87-94.

Momuat, I.M., Suryanto, E. \& Sudewi, S. 2016. The chemical characteristics and antioxidant activity of starch from sago baruk pith (Arenga microcarpha). Molekul. 11(2), 275-287.

Nareswari, A. 2007. Enzim xilanase bacillus licheniformis AQ1: pemekatan, studi termostabilitas dan zimogram. [Skripsi]. Bogor (ID): Institut Pertanian Bogor.

Parra, L.D.C., Saldivar, S.O.S., Liu, H.R. 2007. Effect of processing on the photochemical profile and antioxidant activity of corn for production of masa, tortillas, and tortilla chips. Journal of Algicultural and Food Chemistry. 55(10), 4177-4183.

Popescu, M-C., Singurel, G., Popescu, M-C., Vasile, C., Argyropoulos, D.S. \& Willfor, S. 2009. Vibartional spesctroscopy and $\mathrm{x}$-ray diffraction methods to establish the differences between hardwood and softwood. Carbohydrate Polymer. 77(4), 851-857.

Peng, F., Ren, J.-L., Xu, F., Bian, J., Peng, B. \& Sun, R.-C. 2010. Fractional study of alkali-soluble hemicellulose obtained by graded ethanol precipitation from sugar cane bagasse. Journal of Agricultural and Food Chemistry. 58(3): 1768-1776.

Raghavendra, S.N., Rastogi, N.K. \& Raghavarao K.S.M.S. 2004. Dietary fiber from coconut residue: effects of different treatments and particle size on the hydration properties. European Food Research and Technology. 218(6), 563567.

Ratana-arporn, P. \& Chirapart, A. 2006. Nutritional evaluation of tropical green seaweeds caulerpa lentillifera and ulva reticulata. Journal Kasetsart. 40, 75-83.
Reddy, N. \& Yang, Y. 2005. Structure and properties of high quality natural cellulose fiber from cornstalks. Polymer (Guildf). 46(15), 5494-5500.

Sangaji, I. 2009. Mengoptimalkan pemanfaatan ampas sagu sebagai pakan ruminansia melalui biofermentasi dengan jamur tiram (pleurotus ostreatus) dan amonias [Disertasi]. Bogor (ID): Institut Pertanian Bogor.

Savjani, K.T., Gajjar, A.K. \& Savjani, J.K. 2012. Drug solubility: importance and enhacement techniques. International Scholarly Research Notices Pharmaceutics. 2012, 1-10.

Shanmugarajah, B., Kiew, P.L., Chew, I. M. L., Choong, T. S. Y. \& Tan, K. W. 2015. Isolation of nanocrystalline cellulose (NCC) from palm oil empty fruit bunch (EFB): Preliminary result on FTIR and DLS analysis. Chemical Engineering Transactions. 45, 1705-1710.

Sundari, D., Almasyhuri \& Lamid, A. 2015. Pengaruh proses pemasakan terhadap komposisi zat gizi bahan pangan sumber protein. Media Litbangkes. 25(4), 235242.

Sudarmadji, 1997. Prosedur analisa untuk bahan makanan dan pertanian. Yogyakarta: Liberty.

Trowell, H., Burkitt,D. \& Heaton, K. 1985. Definition of dietary fibre and fibre depleted foods and diseases. London: Academic Press Ltd.

Zhao, X., Zhu, H., Zhang, G. \& Tang, W. 2015. Effect of superfine grinding on the physicochemical properties and antioxidant activity of red grape pomace powders. Powder Technology. 286, 838844.

Zhang, L.H., Xu, H.D., \& Li, S.F. 2009. Effects of micronization on properties of Chaenomeles sinensis (Thouin) Koehne fruit powder. Innovative Food Science and Emerging Technologies. 10(4), 633637. 